\title{
The effect of inhaled frusemide on airway sensitivity to inhaled $4.5 \%$ sodium chloride aerosol in asthmatic subjects
}

\author{
L T Rodwell, S D Anderson, J I du Toit, J P Seale
}

\begin{abstract}
Background Frusemide inhaled by asthmatic subjects before a variety of indirect bronchial challenges inhibits the airway response to these challenges. Since inhalation of hyperosmolar saline is an indirect bronchial challenge, the effect of inhaled frusemide and its vehicle on airway sensitivity to a $4 \cdot 5 \%$ sodium chloride $(\mathrm{NaCl})$ aerosol challenge was investigated.
\end{abstract}

Methods Eleven asthmatic subjects (five females, six males) who had a $20 \%$ fall in forced expiratory volume in one second after $4.5 \% \mathrm{NaCl}$ challenge were enrolled in this double blind controlled crossover trial. Sensitivity was measured as the dose of aerosol required to provoke a $20 \%$ fall in $\mathrm{FEV}_{1}$. Frusemide $\mathbf{3} 33.2$ mg) or its vehicle was delivered through a Fisoneb ultrasonic nebuliser and inhaled 10 minutes before challenge with 4.5\% NaCl. A Mistogen ultrasonic nebuliser was used to generate the $4.5 \%$ $\mathrm{NaCl}$ aerosol and $\mathrm{FEV}_{1}$ was measured before and one minute after each challenge period of 0.5 , one, two, four, eight, eight and eight minutes. The doubling dose difference for $\mathbf{P D}_{20}$ was calculated.

Results Frusemide or vehicle had no effect on baseline lung function. The geometric mean $\mathbf{P D}_{20}$ after vehicle was $1.3 \mathrm{ml}$ with a $95 \%$ confidence interval of $0.7-2.3$ and after frusemide was $8.2 \mathrm{ml}$ with a $95 \%$ confidence interval of 4.7-14.1. This represented a $2 \cdot 6$ doubling dose increase in $\mathbf{P D}_{20}$ after frusemide inhalation. In five of the 11 subjects an increase from baseline $F V_{1}$ occurred after exposure to $4 \cdot 5 \% \mathrm{NaCl}$ challenge in the presence of frusemide. This transient bronchodilatation may be caused by the release of prostaglandin $E_{2}$.

Conclusion Inhalation of frusemide is very effective in delaying airway narrowing induced by an aerosol of $4.5 \% \mathrm{NaCl}$ in asthmatic subjects.

(Thorax 1993;48:208-213)

Frusemide when given by inhalation to asthmatic subjects inhibits the airway narrowing provoked by exercise ${ }^{12}$ and hyper- ventilation. $^{34}$ It also inhibits the airway response to distilled water, ${ }^{56}$ allergen, ${ }^{7}$ metabisulphite, ${ }^{8}$ and adenosine 5 '-monophosphate. ${ }^{9}$ Its effect on challenge with hyperosmolar saline has been reported only in abstract form. ${ }^{10}$

The precise mechanism by which frusemide inhibits the airway responses to this wide variety of provoking stimuli is still unknown. Its inhibitory effect on these challenges suggest that one possible mode of action may be in preventing release of mediators from mast cells. The in vitro finding that frusemide is effective in inhibiting the release of histamine and leukotrienes from passively sensitised human lung tissue in response to an allergen challenge supports this suggestion. ${ }^{11}$

Hypertonic saline when inhaled by asthmatic subjects is thought to cause airway narrowing by releasing histamine from mast cells in the airways in response to an increase in airway osmolarity. ${ }^{12-16}$ The antihistamines terfenadine (given orally) and clemastine (given as an aerosol) are effective in reducing the airway narrowing provoked by an increase in airway osmolarity. ${ }^{17-19}$ As frusemide inhibits the release of histamine and other mast cell mediators it would be expected that frusemide would also inhibit airway narrowing when inhaled before a hypertonic saline challenge.

The purpose of this study was to compare the effects of frusemide given as an aerosol with its vehicle on airway responsiveness to $4.5 \% \mathrm{NaCl}$ aerosol in a group of asthmatic subjects sensitive to increases in airway osmolarity.

\section{Methods}

SUBJECTS

Eleven clinically stable asthmatic subjects (five females, six males) ranging in age from 19 to 41 years with a mean age of $24 \cdot 1$ years attended the Respiratory Investigation Unit on three occasions over a period of $\mathbf{4 5}$ days. The subjects studied had a $20 \%$ fall in forced expiratory volume in one second $\left(\mathrm{PD}_{20} \mathrm{FEV}_{1}\right)$ after inhaling less than $18.0 \mathrm{ml}$ of $4.5 \%$ $\mathrm{NaCl}$. Anthropometric details, regular asthma medications, mean prechallenge percentage predicted FEV 1 values for the control 
Anthropometric details, mean prechallenge values for forced expiratory volume in one second ( $F E V$ ) expressed as a percentage of the predicted value, provoking dose of $4.5 \%$ $\mathrm{NaCl}$ that caused a $20 \%$ fall in $\mathrm{FEV}$, on the control day $\left(P D_{20} F E V_{1}\right)$, regular medications, and daily dose of inhaled beclomethasone dipropionate (values expressed as the geometric mean with $95 \%$ confidence interval)

\begin{tabular}{|c|c|c|c|c|c|c|}
\hline Subject & $\begin{array}{l}\text { Age } \\
\text { (years) }\end{array}$ & Sex & $\begin{array}{l}F E V, \\
\text { (\% predicted) }\end{array}$ & $\begin{array}{l}P D_{20} F E V_{1} \\
\text { on control day } \\
(\mathrm{ml})\end{array}$ & $\begin{array}{l}\text { Regular } \\
\text { medications }\end{array}$ & $\begin{array}{l}\text { Daily dose } \\
\text { of } B D P \\
(\mu g)\end{array}$ \\
\hline 1 & 26 & $\mathbf{M}$ & $62 \cdot 7$ & 0.91 & S & - \\
\hline 2 & 22 & $\mathbf{M}$ & $89 \cdot 4$ & 0.80 & S & - \\
\hline 3 & 20 & $\mathrm{~F}$ & $95 \cdot 5$ & $6 \cdot 80$ & Ter,BDP & 1000 \\
\hline 4 & 30 & $\mathrm{~F}$ & $79 \cdot 0$ & $2 \cdot 93$ & S,I,BDP & 1500 \\
\hline 5 & 24 & $\mathrm{~F}$ & $113 \cdot 1$ & $3 \cdot 80$ & $\mathrm{~S}, \mathrm{~T}, \mathrm{BDP}$ & 2000 \\
\hline 6 & 20 & $\mathrm{~F}$ & $97 \cdot 6$ & 1.49 & S,BDP & 2000 \\
\hline 7 & 20 & $\mathrm{M}$ & $89 \cdot 2$ & 6.92 & $\mathrm{~S}$ & - \\
\hline 8 & 22 & $\mathrm{~F}$ & $90 \cdot 5$ & $2 \cdot 29$ & S,BDP & 1000 \\
\hline 9 & 19 & $\mathrm{M}$ & $121 \cdot 8$ & $3 \cdot 17$ & $\mathrm{~S}$ & - \\
\hline 10 & 41 & $\mathbf{M}$ & $72 \cdot 8$ & 0.89 & $\mathrm{~F}$ & - \\
\hline 11 & 21 & M & $87 \cdot 8$ & 0.47 & S,BDP & 1500 \\
\hline \multirow{2}{*}{$\begin{array}{l}\text { Mean } \\
\text { (SD) }\end{array}$} & \multirow{2}{*}{\multicolumn{2}{|c|}{$24 \cdot 1(6 \cdot 5)$}} & & & & \\
\hline & & & $90.9(16 \cdot 7)$ & \multicolumn{2}{|c|}{$1.97(95 \%$ CI $1 \cdot 16-3.35)$} & \\
\hline
\end{tabular}

S-salbutamol; Ter-terbutaline; F-fenoterol; BDP-beclomethasone dipropionate; I-ipratropium bromide; $\mathrm{T}$-theophylline

day and $\mathrm{PD}_{20} \mathrm{FEV}_{1}$ values (ml) in response to the $4.5 \% \mathrm{NaCl}$ challenge on the control day for the 11 asthmatic subjects are listed in the table.

Beta $_{2}$ adrenoceptor agonists were withheld for more than six hours, ipratropium bromide for more than eight hours and theophylline for more than 12 hours before the $4.5 \% \mathrm{NaCl}$ challenge. Six of the 11 subjects had been taking beclomethasone dipropionate by inhalation on a daily basis for at least eight weeks. This was also withheld for at least six hours before the challenge. All subjects were atopic and had a positive skin reaction to one or more of eight common allergens. Subjects were asked about recent symptoms of wheeze or dyspnoea. If there was an increase in these symptoms in the previous 24 hours, testing did not proceed. The protocol was fully explained and consent was obtained in writing from each subject. The study was approved by the Ethics Committee of the Royal Prince Alfred Hospital.

METHODS

Frusemide and its vehicle

Ampoules of frusemide (Lasix; Hoechst, Germany) each containing $20 \mathrm{mg}$ frusemide in $2 \mathrm{ml}(10 \mathrm{mg} / \mathrm{ml})$ with a $\mathrm{pH}$ of 9 were used in the study. The vehicle was $0.9 \% \mathrm{NaCl}$ adjusted daily by the investigator to a $\mathrm{pH}$ of $8 \cdot 9-9.2$ by adding $0.01 \mathrm{~mol} / 1$ sodium hydroxide. A pH meter (Radiometer PHM 62, Copenhagen, Denmark) was used to measure the $\mathrm{pH}$ of the frusemide and its vehicle. The osmolality of the frusemide and its vehicle was 303 mosmol as measured by freezing point depression (Advanced Cryomatic Osmometer, Model Advanced Instruments, Massachusetts, USA). Both the active and vehicle solutions were given to a pharmacist with the randomised code and one returned to the investigator to administer to the subject. This was a double blind vehicle controlled randomised crossover study.

Delivery of frusemide and its vehicle

A Fisoneb ultrasonic nebuliser (Fisons, Rochester, New York, USA) producing a dense aerosol with a mass median aerodynamic diameter of $4 \cdot 7 \mu \mathrm{m}$ was used to deliver both the frusemide and the vehicle. The output of the nebuliser was placed on the maximum setting for the duration of the study.

To give a dose of frusemide similar to that used in published studies ${ }^{1-3568} 6 \mathrm{ml}$ of frusemide or vehicle was placed in the Fisoneb and inhaled for seven minutes. The aerosol was delivered via a mouthpiece while the subject wore a nose clip. The unit was weighed (Sartorius Analytic, Gottingen, Germany) before and after nebulisation and a stopper placed in the output hole during weighing to reduce loss of volume by evaporation. The difference in weight change was recorded as the amount of frusemide or vehicle nebulised. The mean (SD) amount of frusemide nebulised was $33 \cdot 2(3 \cdot 8) \mathrm{mg}$.

AEROSOL CHALLENGE WITH $4.5 \%$ NACL

The protocol used to perform the $4.5 \% \mathrm{NaCl}$ challenge is described in detail by Smith and Anderson. ${ }^{16}$ The maximum dose of aerosol delivered, however, was approximately $2 \cdot 5$ times greater than in the original protocol and spirometric values were recorded in duplicate only one minute (not one and a half minutes) after each challenge period. The highest $\mathrm{FEV}_{1}$ measured one minute after each challenge period was then used in the analysis of the data.

The $4.5 \% \mathrm{NaCl}$ challenge aerosol was generated by a $\mathrm{MistO}_{2}$ gen Ultrasonic Nebuliser (Timeter, Pennsylvania, USA). Subjects inhaled the aerosols at resting ventilation rates through a two way valve (Hans Rudolf 2700, Kansas City, Missouri, USA) and mouthpiece connected to the ultrasonic nebuliser by internally non-corrugated tubing $67.5 \mathrm{~cm}$ in length with an internal diameter of $22 \mathrm{~mm}$. This unit was weighed before and after the final dose of aerosol had been delivered.

Subjects inhaled the challenge aerosol for half a minute and waited one minute and then spirometry was performed. If there was a $20 \%$ fall in $\mathrm{FEV}_{1}$ from the baseline $\mathrm{FEV}_{1}$ the challenge was stopped and the subject included in the study. If a $20 \%$ fall was not recorded, the challenge continued for further intervals of one, two, four, eight, eight and eight minutes or until the provoking dose causing a $20 \%$ fall in $\mathrm{FEV}_{1}\left(\mathrm{PD}_{20} \mathrm{FEV}_{1}\right)$ could be recorded.

\section{STUDY DESIGN}

Subjects were required to attend the laboratory on three occasions. On the control day subjects were accepted into the study if a $\mathrm{PD}_{20} \mathrm{FEV}_{1}$ in response to the $4.5 \% \mathrm{NaCl}$ aerosol challenge was recorded. They then returned for two further visits when either frusemide or the vehicle was administered before the challenge with $4 \cdot 5 \% \mathrm{NaCl}$.

A minimum of three days separated all visits to ensure that the medication had cleared from the airways. The maximum time between visits was eight days and the study was completed in 45 days. 
Control day (visit 1)

On arrival at the laboratory, spirometry (Minato Autospirometer AS500, Osaka, Japan) was performed in triplicate and then repeated ten minutes later to establish that the airway measurement was stable. The baseline $\mathrm{FEV}_{1}$ was taken as the best FEV value recorded immediately before the challenge.

Frusemide and vehicle day (visits two and three) The protocol for visits two and three was the same as for the control day, except that subjects inhaled the frusemide or its vehicle ten minutes before the $4.5 \% \mathrm{NaCl}$ aerosol challenge. The challenge was stopped when either a $30 \%$ fall in $\mathrm{FEV}_{1}$ was recorded or the last dose of aerosol was delivered.

\section{ANALYSIS OF DATA}

Baseline lung function

The percentage predicted values for $\mathrm{FEV}_{1}$ were compared before and ten minutes after either the frusemide or its vehicle was delivered. A two way analysis of variance was used to assess if there were any differences in the percentage predicted ${ }^{20} \mathrm{FEV}_{1}$ on the control day and before and ten minutes after inhaling either the frusemide or its vehicle. A level of $p$ below 0.05 was considered significant. A paired $t$ test was used to assess the effect of frusemide or its vehicle on baseline lung function.

Changes in airway sensitivity to $4.5 \% \mathrm{NaCl}$ challenge: $P D_{20} F E V_{1}$

The provoking dose of $4.5 \% \mathrm{NaCl}(\mathrm{ml})$ which caused a $20 \%$ fall in $\mathrm{FEV}_{1}$ was used as an index of airway sensitivity and changes in $\mathrm{PD}_{20}$ were used to assess the effects of inhaling frusemide. A paired $t$ test was used to test for differences in the $P_{20} F E V_{1}$ between frusemide and its vehicle and between the vehicle and the control. All $\mathrm{PD}_{20} \mathrm{FEV}_{1}$ values were expressed as the geometric mean. If a $20 \%$ fall in $\mathrm{FEV}_{1}$ was not recorded on a challenge day the maximum dose of $4.5 \% \mathrm{NaCl}$ delivered on that challenge day was recorded as the $\mathrm{PD}_{20}$ value.

\section{Doubling dose interval}

Changes in $\mathrm{PD}_{20} \mathrm{FEV}_{1}$ resulting from administration of frusemide when compared with its vehicle and the vehicle when compared with the control day were expressed in doubling doses (95\% confidence intervals (CI)). The doubling dose interval was used to express the results because the $4.5 \% \mathrm{NaCl}$ aerosol was generally delivered in doubling doses.

\section{Results}

Frusemide $(33.2 \mathrm{mg})$ inhaled ten minutes before challenge reduced airway sensitivity $\left(\mathrm{PD}_{20}\right)$ to $4.5 \% \mathrm{NaCl}$ when compared with its vehicle (fig 1). The $\mathrm{PD}_{20} \mathrm{FEV}_{1}$ increased from $1.3 \mathrm{ml}(95 \% \mathrm{CI} 0 \cdot 7-2 \cdot 3)$ after administration of the vehicle to $8.2 \mathrm{ml}(95 \% \mathrm{CI}$ $4 \cdot 7-14 \cdot 1)$ after frusemide ( $<<0.001, \mathrm{n}=$ 11). This represented an increase of $2.6(95 \%$
CI 2.2-3.1) doubling doses in airway sensitivity as measured by $\mathrm{PD}_{20} \mathrm{FEV}_{1}$. When the results after administration of the vehicle were compared with those on the control day there was a decrease of $0.6(95 \%$ CI $0.3-1.4)$ doubling doses in airway sensitivity; this was not significant (fig 1).

The mean (SD) baseline percentage predicted $\mathrm{FEV}_{1}$ was not changed ten minutes $\stackrel{0}{\rightarrow}$ after inhalation of either frusemide, 85.4 . $(15 \cdot 1) v 87.9(14.4)$ or its vehicle, $85.3(20 \cdot 0)$ $v 85 \cdot 2(18 \cdot 1)$.

The mean (SD) percentage fall in $\mathrm{FEV}_{1} \stackrel{\varnothing}{\stackrel{\circ}{\circ}}$ obtained after the highest dose of $4.5 \% \mathrm{NaCl}$ के common to the three test days had been $\overrightarrow{0}$ delivered was $33.3(12 \cdot 6) \%$ for the control, $\overrightarrow{\vec{\omega}}$ $37.6(10.6) \%$ for the vehicle, and $7.5(4.9) \%$ 。 for frusemide. This occurred at the highest $\overrightarrow{\vec{x}}$ common dose of $4.5 \% \mathrm{NaCl}$, which was $3 \cdot 8 \mathrm{ml} \mathrm{(95 \%} \mathrm{CI} 2 \cdot 4-6 \cdot 0)$.

Individual dose-response curves for the $\tilde{N}$ control, vehicle, and frusemide days for the $\infty$

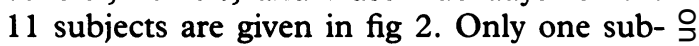
ject (No 3) did not record a $\mathrm{PD}_{20}$ in response $\vec{T}$ to $4.5 \% \mathrm{NaCl}$ after inhaling frusemide. In this subject the $\mathrm{FEV}_{1}$ fell $13 \cdot 1 \%$ after a maximum dose of $30.8 \mathrm{ml} 4.5 \% \mathrm{NaCl}$ had been delivered.

In five of the 11 subjects (Nos $1,2,3,4$ and 5) an increase in $\mathrm{FEV}_{1}$ occurred during

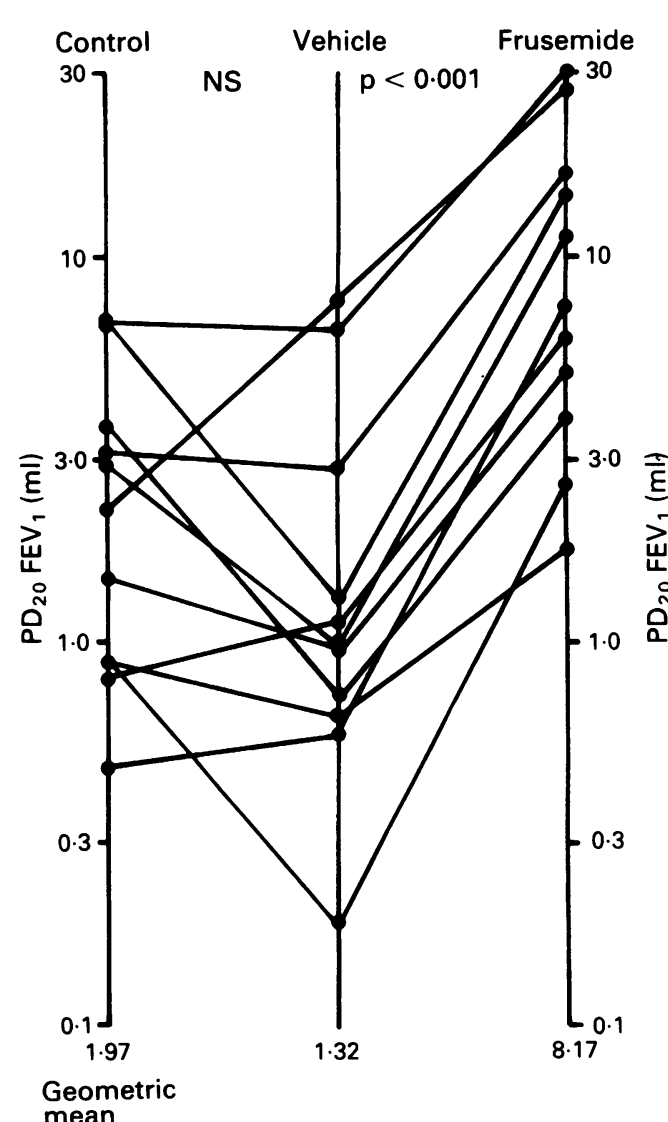

Figure 1 Provoking dose of $4 \cdot 5 \% \mathrm{NaCl}(\mathrm{ml})$ which caused a $20 \%$ fall in FEV $\left(P D_{20} F E V_{1}\right)$ on the control day, and after administration of vehicle and frusemide. Where a $20 \%$ fall in FEV, was not recorded the maximum dose of $4.5 \% \mathrm{NaCl}$ delivered on the challenge day was taken as the $P D_{20}$. The geometric mean values and $95 \%$ confidence intervals (CI) were: 1.97 (95\% CI 1.16-3.35) on the control day, $1 \cdot 32(95 \%$ CI $0 \cdot 74-2 \cdot 34)$ after administration of the vehicle, and 8.17 (95\% CI 4.73-14.12) afier frusemide. 
Figure 2 Individual doseresponse curves for the 11 subjects on the control day and after administration of vehicle and frusemide.

Results are expressed as the percentage fall in $F E V$, in relation to the cumulative dose of $4.5 \% \mathrm{NaCl}(\mathrm{ml})$ delivered on each test day. Control, $\mathbf{0 - 1}$; vehicle, --- ; frusenide,

Note: 0.01 on the $x$ axis represents prechallenge values.
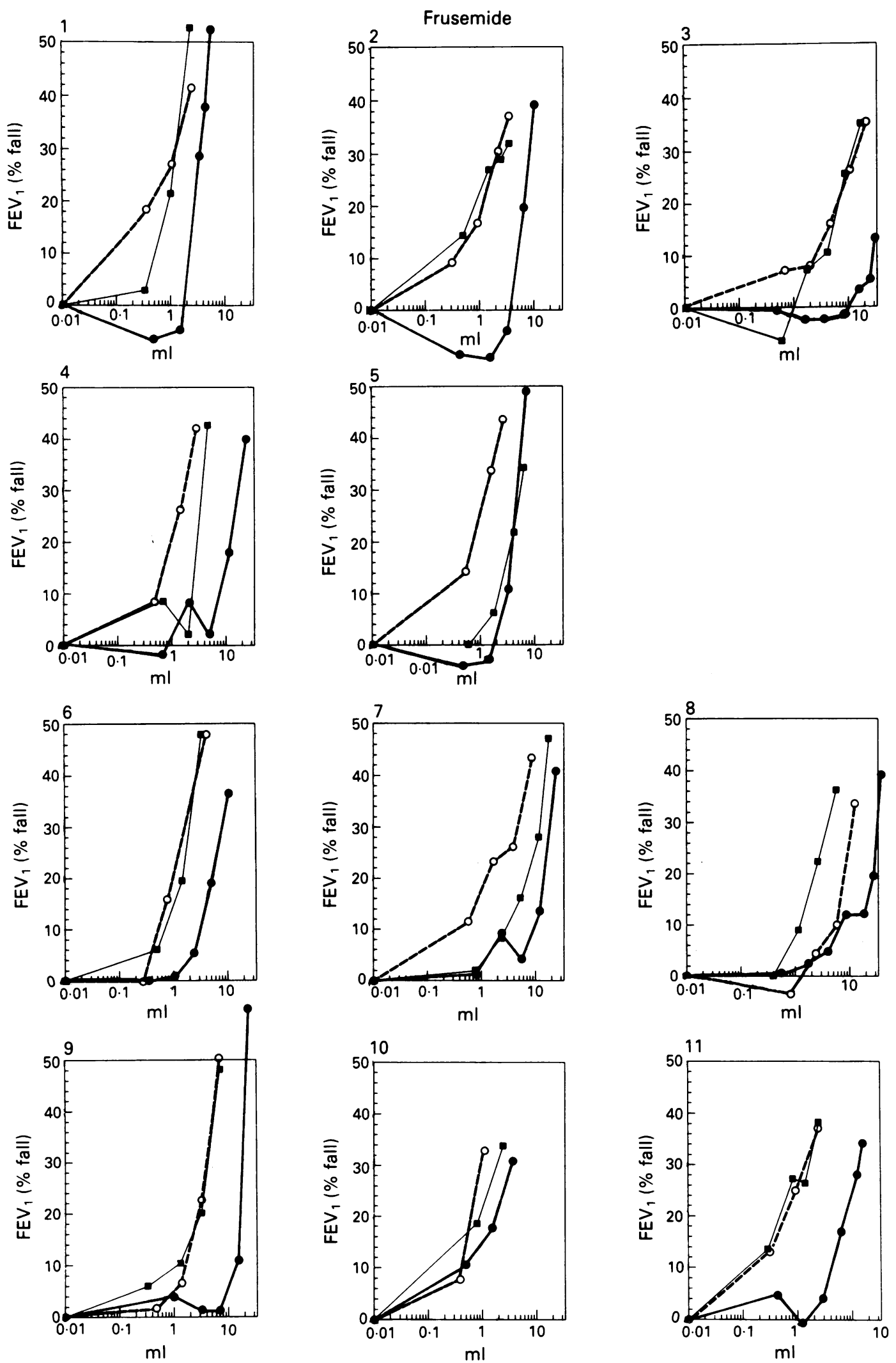

the first five minutes of inhaling $4.5 \% \mathrm{NaCl}$ in the presence of frusemide. Of these five subjects, Nos 1 and 2 had the lowest percentage predicted $\mathrm{FEV}_{1}$ after frusemide inhalation before $4.5 \% \mathrm{NaCl}$ challenge $(69 \cdot 2 \%$ and $68.7 \%$ respectively) and they had the greatest improvement in $\mathrm{FEV}_{1} \quad(7 \cdot 5 \%$ and $9 \cdot 4 \%$ increase from baseline respectively).

\section{Discussion}

This study has shown that compared with its vehicle inhaled frusemide caused a significant decrease in airway sensitivity to challenge with a $4.5 \% \mathrm{NaCl}$ aerosol in asthmatic subjects. Evidence that a change in airway sensitivity to $4.5 \% \quad \mathrm{NaCl}$ had occurred after inhalation of frusemide was shown by the $2 \cdot 6$ doubling dose decrease in $\mathrm{PD}_{20} \mathrm{FEV}_{1}$. Frusemide also significantly reduced the percentage fall in $\mathrm{FEV}_{1}$ at the highest delivered dose of $4.5 \% \mathrm{NaCl}$ common to the three test days when compared with its vehicle.

These results are consistent with previous 
reports of the protective effect of inhaled frusemide on other airway challenges which are thought to involve changes in airway osmolarity-for example, exercise, ${ }^{12}$ hyperventilation, ${ }^{3}$ and water. ${ }^{56}$

It was interesting to note that the protective effect of frusemide was overcome with continued exposure to the $4.5 \% \mathrm{NaCl}$. No plateau in the airway response was observed and in 10 of the 11 subjects the final percentage fall in $\mathrm{FEV}_{1}$ was similar to the value observed on the day the vehicle was given. This contrasts with our findings with nedocromil sodium, in which half the subjects studied had their airway responses completely inhibited or a plateau occurred in their airway response to $4.5 \% \mathrm{NaCl}^{21}$

A new finding in this study was the improvement in $\mathrm{FEV}_{1}$ during the inhalation of $4.5 \% \mathrm{NaCl}$ in the presence of frusemide. Five subjects had values for $\mathrm{FEV}_{1}$ that were higher than baseline values. There was no change in $\mathrm{FEV}_{1}$ in the 10 minutes after administration of frusemide and before the challenge with $4.5 \% \mathrm{NaCl}$. It is possible that these changes in $\mathrm{FEV}_{1}$ early in the challenge were due to the release of a bronchodilating substance in the presence of frusemide. The effect was short but long enough to increase significantly the dose of $4.5 \% \mathrm{NaCl}$ aerosol required to produce a $20 \%$ fall in $\mathrm{FEV}_{1}$. Frusemide therefore reduced the sensitivity of the airways to hyperosmolar challenge but did not prevent the airways from narrowing in response to the same concentration of saline when given at a higher dose.

We think that it is unlikely that frusemide itself is acting as a functional antagonist as it provides little or no protection against histamine challenge ${ }^{22}$ and inconsistent protection against methacholine challenge ${ }^{323}$ and did not ultimately protect the airways from narrowing in this study.

There are several mechanisms by which frusemide may act to inhibit airway narrowing caused by $4.5 \% \mathrm{NaCl}$ aerosol. One mechanism is to prevent or delay the release of inflammatory mediators from mast cells, possibly by blocking $\mathrm{Cl}^{-}$site at the $\mathrm{Na}^{+} / \mathrm{K}^{+} / 2 \mathrm{Cl}^{-}$ cotransporter on the mast cell membrane. ${ }^{11}$ Another mechanism is the inhibition of the $\mathrm{Na}^{+} / \mathrm{K}^{+} / 2 \mathrm{Cl}^{-}$cotransporter ${ }^{24}$ at a chloride site at the basolateral surface of the airway epithelial cell. ${ }^{25}$ During challenge with $4.5 \%$ $\mathrm{NaCl}$ aerosol the subsequent hyperosmolarity of the airway lumen may stimulate the movement of water by osmosis first from the epithelial cells and then from the submucosa. The action of frusemide may be in reducing the potential for the submucosa to become dehydrated by blocking the movement of water by its action on the $\mathrm{Na}^{+} / \mathrm{K}^{+} / 2 \mathrm{Cl}^{-}$ cotransporter while permitting water loss from the epithelial cell in response to an osmotic stimulus. Protecting the submucosa from possible dehydration and consequent increases in osmolarity ${ }^{26}$ would decrease the potential for further mediator release from mast cells and cause $C$ afferent fibres to fire ${ }^{27}$ and microvascular leakage. ${ }^{28}$ All these events could contribute to the airway narrowing provoked by the inhalation of $4.5 \% \mathrm{NaCl}$.

A simple explanation for the protective effect of frusemide on a wide variety of challenges may be its ability to generate prostaglandin $\mathrm{E}_{2}\left(\mathrm{PGE}_{2}\right),{ }^{29}{ }^{30}$ a relaxant of bronchial smooth muscle. $\mathrm{PGE}_{2}$ may be released from epithelial cells secondary to hyperosmolarity, a stimulus known to generate $\mathrm{PGE}_{2}$ production in the stomach, which is an embryologically related organ. ${ }^{31}$ The transient nature of the bronchodilatation is in keeping with the short half life of this substance. ${ }^{32}$ It may also be expected that, as the hyperosmolar challenge continues, mediators released from mast cells which cause bronchoconstriction override the protective effect afforded by the prostaglandins and the airways narrow. Indomethacin reduces the protective effect of inhaled frusemide against exercise induced asthma. ${ }^{33}$ This implicates prostaglandins in the protective effect of frusemide against osmotic bronchial challenges as an increase in airway osmolarity is thought to be the mechanism causing the airways to narrow in both exercise induced asthma and asthma induced by inhaling hyperosmolar aerosols. ${ }^{34}$ Other studies have shown that prostaglandin synthetase inhibitors enhance the protective effect of inhaled frusemide against metabisulphite ${ }^{35}$ and ultrasonically nebulised water $^{36}$ bronchial challenges in asthmatic subjects. This suggests that prostaglandins may contribute to airway narrowing caused by these challenges. In our study, however, there may $\overrightarrow{\vec{\rho}}$ be a unique synergy between frusemide and hypertonic saline in releasing bronchodilator prostaglandins such as $\mathrm{PGE}_{2}$.

This study shows that frusemide is very effective in delaying the airway narrowing induced in response to $4.5 \% \mathrm{NaCl}$ in asthmatic subjects, thereby reducing sensitivity to hyperosmolar challenge. Although its precise mechanism of action remains uncertain, inhi- $₹$ bition of the $\mathrm{Na}^{+} / \mathrm{K}^{+} / 2 \mathrm{Cl}^{-}$cotransporter at 0 the $\mathrm{Cl}^{-}$site on the epithelial cells, mast cells, and nerves and enhanced release of bronchodilating substance(s), or both, may be responsible.

This research was partly funded (LR) by the National Health and Medical Research Council of Australia.

1 Bianco $S$, Vaghi A, Robuschi $M$, Pasargiklian $M$. Prevention of exercise-induced bronchoconstriction by inhaled furosemide. Lancet 1988; 252-5.

2 Feather IR, Olson LG. Frusemide antagonises exercise- $\mathbb{D}$ induced but not histamine-induced bronchospasm. Aust $\frac{\Phi_{\overparen{D}}}{\mathrm{Q}}$ NZ F Med 1991;21:7-10.

3 Grubbe RE, Hopp R, Dave NK, Brennan B, Bewtra A, $\sigma$ Townley R. Effect of inhaled furosemide on the bronchial response to methacholine and cold-air hyper- 8 ventilation challenges. F Allergy Clin Immunol 1990;85: $881-4$.

4 O'Donnell WJ, Rosenberg M, Niven RW, Drazen JM, Israel E. Acetazolamide and furosemide attenuate asthma induced by hyperventilation of cold, dry air. $A m R e v$ Respir Dis 1992;143:A211.

5 Robuschi M, Gambaro G, Spagnotto S, Vaghi A, Bianco $S$. Inhaled furosemide is highly effective in preventing . In ultrasonically nebulised water br
Pulmonary Pharmacol 1989;1:187-91.

6 Moscato G, Dellabianca A, Falagiani P, Mistrello G, Rossi G, Rampulla C. Inhaled furosemide prevents both the bronchoconstriction and the increase in neutrophil 
chemotactic activity induced by ultrasonic "fog" of distilled water in asthmatics. Am Rev Respir Dis 1991; 143:561-6.

7 Bianco S, Pieroni MG, Refini RM, Rottoli L, Sestini P. Protective effect of inhaled furosemide on allergeninduced early and late asthmatic reactions. $N$ Engl $f$ Med 1989;321:1069-73.

8 Nichol GM, Alton EWFW, Nix A, Geddes DM, Chung $\mathrm{KF}$, Barnes PJ. Effect of inhaled furosemide on metabisulfite and methacholine induced bronchoconstriction and nasal potential difference in asthmatic subjects. Am Rev Respir Dis 1990;142:576-80.

9 Polosa R, Lau LCK, Holgate ST. Inhibition of adenosine 5'-monophosphate- and methacholine-induced bronchoconstriction in asthma by inhaled frusemide. Eur Respir f 1990;3:665-72.

10 Robuschi M, Vaghi A, Gambaro G, Spagnotto S, Bianco $S$. Inhaled furosemide $(F)$ is effective in preventing ultrasonically nebulised $5.8 \% \mathrm{NaCl}$ bronchoconstriction. Eur Respir f 1988;1(Suppl 2):194S.

11 Anderson SD, Wei HE, Temple DM. Inhibition by furosemide of inflammatory mediators from lung fragments. N Engl f Med 1991;324:131.

12 Eggleston PA, Kagey-Sobotka A, Lichtenstein LM. A comparison of the osmotic activation of basophils and human lung mast cells. Am Rev Respir Dis 1987;135: 1043-8.

13 Belcher NG, Murdoch RD, Dalton N, House FR, Clark TJH, Rees PJ, et al. A comparison of mediator and catecholamine release between exercise and hypertonic saline-induced asthma. Am Rev Respir Dis 1988;137: 1026-32.

14 Gravelyn TR, Pan PM, Eschenbacher WL. Mediator release in an isolated airway segment in subjects with asthma. Am Rev Respir Dis 1988;137:641-6.

15 Silber G, Proud D, Warner J, Naclerio R, Kagey-Sobotka $\mathrm{A}$, Lichtenstein $\mathrm{L}$, et al. In vivo release of inflammatory mediators by hyperosmolar solutions. Am Rev Respir Dis 1988;137:606-12.

16 Smith CM, Anderson SD. Inhalation provocation tests using nonisotonic aerosols. f Allergy Clin Immunol 1989;84:781-90.

17 Finnerty JP, Wilmot C, Holgate ST. Inhibition of hypertonic saline-induced bronchoconstriction by terfenadine and flurbiprofen. Am Rev Respir Dis 1989;140:593-7.

18 Finney MJB, Anderson SD, Black JL. Terfenadine modifies airway narrowing induced by the inhalation of nonisotonic aerosols in subjects with asthma. Am Rev Respir Dis 1990;141:1151-7.

19 Rodwell LT, Anderson SD, Seale JP. Inhaled clemastine, an $\mathrm{H}_{1}$ antihistamine inhibits airway narrowing caused by aerosols of non-isotonic saline. Eur Respir $\mathcal{f} 1991 ; 4$ 1128-34.

20 Goldman HI, Becklake MR. Respiratory function tests Normal values at medium altitudes and the prediction of normal results. Am Rev Respir Dis 1959;79:457-67.

21 Rodwell LT, Anderson SD, du Toit JI, Seale JP.
Nedocromil sodium inhibits the airway response to hyperosmolar challenge in patients with asthma. $A m$ Rev Respir Dis 1992;146:1149-55.

22 Vaghi A, Robuschi M, Bianco S. Effect of inhaled furosemide $(F)$ on bronchial response to histamine $(\mathrm{H})$ in asthmatics. Eur Respir f 1988;1(Suppl 2):406S

23 Fujimura M, Sakamoto S. Effect of inhaled furosemide on bronchial responsiveness to methacholine. $N$ Engl $\mathcal{F ~ M e d}$ 1990;322:935-6.

24 Welsh MJ. Inhibition of chloride secretion of furosemide in canine tracheal epithelium. Membrane Biol 1983;71: 219-26.

25 Widdicombe JH, Nathanson IT, Highland E. Effects of "loop" diuretics on ion transport by dog tracheal epithelium. Am F Physiol 1983;245(Cell Physiol14):C388-96.

26 Anderson SD, Daviskas E. The airway microvasculature and exercise induced asthma. Thorax 1992;47:748-52.

27 Pisarri TE, Jonson A, Coleridge HM, Coleridge JCG Intravenous injection of hypertonic $\mathrm{NaCl}$ solution stimulates pulmonary C fibres in dogs. Am $\mathcal{F}$ Physiol 1991; 260(Heart Circ Physiol29):H1522-30.

28 Umeno E, McDonald DM, Nadel JA. Hypertonic saline increases vascular permeability in the rat trachea by producing neurogenic inflammation. I Clin Invest 1990; 85:1905-8.

29 Miyanoshita A, Terada M, Endou H. Furosemide directly stimulates prostaglandin $E_{2}$ production in the thick ascending limb of Henle's loop. F Pharmacol Exp Ther 1989;251:1155-9.

30 Weber PC, Scherer B, Larsson C. Increase of free arachidonic acid by furosemide in man as the cause of prostaglandin and renin release. Eur $\mathcal{F}$ Pharmacol 1977; 41:329-32.

31 Assouline G, Leibson V, Danon A. Stimulation of prostaglandin output from rat stomach by hypertonic solutions. Eur $\mathcal{F}$ Pharmacol 1977;44:271-3.

32 Robertson RP. Eicosanoids and human disease. In: Wilson JD, Braunwald E, Isselbacher KJ, Petersdorf RG, Martin JB, Fauci AS, et al eds. Harrison's principles of internal medicine. 12th edn (Vol 1). New York: McGraw-Hill, 1991: 397-401.

33 Pavord ID, Wisniewski A, Tattersfield AE. Inhaled furosemide and exercise induced asthma: evidence of
a role for inhibitory prostanoids. Thorax 1992;47: a role for

34 Anderson SD. Is there a unifying hypothesis for exerciseinduced asthma? $\mathcal{F}$ Allergy Clin Immunol 1984;73:660-5.

35 O'Connor BJ, Ridge SM, Barnes PJ, Chung KF. The role of cyclooxygenase products in the inhibition of sodium metabisulphite-induced bronchospasm by furosemide in asthma. Am Rev Respir Dis 1991;143:A219.

36 Bianco S, Vaghi A, Pieroni MG, Robuschi M, Refini RM, Sestini P, et al. Potentiation of the protective effect of inhaled furosemide on the bronchial obstructive response to ultrasonically nebulised water by inhaled lysine acetylsalicylate. Eur Respir $\mathcal{f}$ 1991;4(Suppl 14): $606 \mathrm{~S}$. 